\title{
Evaluation of different approaches for modelling individual tree seedling height growth
}

\author{
Sven Wagner $\cdot$ Palle Madsen $\cdot$ Christian Ammer
}

Received: 3 April 2008/Revised: 7 January 2009/Accepted: 13 January 2009/Published online: 12 February 2009

(C) The Author(s) 2009. This article is published with open access at Springerlink.com

\begin{abstract}
We compared different approaches for modelling height growth of individual beech seedlings in a controlled factorial experiment as well as in field data from naturally regenerated beech seedlings under the canopy of overstorey mature beech trees. Several competition indices, a model of overstorey fine root density, relative photosynthetically active radiation (PAR) values, and soil water values were used in these approaches. In the factorial experiment relative $P A R$ and soil water content were measured and used for the prediction of seedlings height growth. In the field experiment this was done by using relative $P A R$ and estimated fine root biomass as a surrogate for below ground resource availability. The latter approach was compared with a model where we used various competition indices representing the impact of overstorey trees on beech seedlings. Our results suggested that (1) models which combine resource based growth functions are suitable for the prediction of individual height growth of beech
\end{abstract}

Communicated by T. Grams.

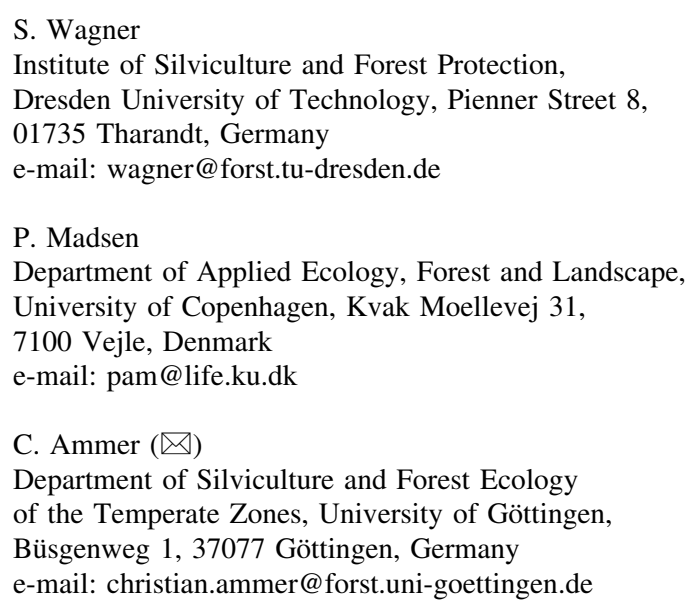

seedlings. Resource based models offer the opportunity to investigate on the independent multiplicative effect of irradiance and water supply and their interactions on tree seedlings. It was (2) shown that a combined model could be used not only to predict individual height growth of beech seedlings in a controlled experiment but also in the field. The model parameters of a pure light response function for the controlled factorial experiment are comparable to those obtained in the field study. The results showed (3) that the precision of predicting beech seedlings height growth is comparable between the model types tested within this study. Approximately half of the observed variation in seedlings relative height growth rate could be explained. However, the simple competition index approach provides no information on the environmental factors constraining tree seedlings growth; whereas the multiplicative combined models can be used to get a better understanding of growth dynamics in the field.

Keywords Resource-based model - Fagus sylvatica (L.) . Competition index $\cdot$ Regeneration ecology

\section{Introduction}

It is widely accepted that the canopy density of overstorey trees has a strong impact on survival and growth of understory seedlings and saplings (Beaudet and Messier 1998; Collet et al. 2001, 2002; Claveau et al. 2002; Kneeshaw et al. 2002). This knowledge is utilized in practical silviculture for the control of competition processes in mixtures of natural regeneration and seedling morphology (Wagner 1999; Wagner and Lundqvist 2004). The regarding silvicultural techniques are based on the fact that a mature stand determines the resource availability of other functional groups 
within forest ecosystems and hence reduces growing space (sensu Oliver and Larson 1996). Growing space can therefore be seen as a surrogate to resource availability in so far, as overstorey trees affect the resource pool, e.g. of seedlings by their leaves and roots (Aussenac 2000; Collet et al. 2001). For many purposes it is sufficient to know that growing space, which can be easily expressed by competition indices, affects seedling survival and growth. For a profound understanding of regeneration dynamics and the ecologically founded further development of natural regeneration techniques however, it is essential to identify the factors influencing growth and shape of seedlings and saplings (Aussenac 2000). Moreover, examining these factors and their interactions may reveal mechanisms of both succession and managed natural regeneration processes (see Grubb et al. 1996; Battaglia et al. 2000).

One approach to study the effect of environmental factors and their interactions is to focus on the response of seedlings to limited resources (Goldberg 1990). However, this approach requires efficient measurement techniques for the evaluation of resource availability. As a consequence of the ongoing improvements in measurement technique which have been achieved, e.g. in photosynthetically active radiation (PAR)-sensors (overview in Dohrenbusch 1995) or in hemispherical photography (Chazdon and Field 1987; Rich 1990; Wagner et al. 2004), particularly the knowledge about the importance of PAR on survival and growth of seedlings has been improved very much (e.g. von Lüpke 1987; Comeau et al. 1993; Pacala et al. 1996; Collet et al. 1997; van Hees 1997; Gardiner and Hodges 1998; Welander and Ottosson 1998; Coates and Burton 1999; Williams et al. 1999; Kaelke et al. 2001; Aranda et al. 2002; Ammer 2003). In contrast to light, knowledge about the importance of belowground resources for seedling vitality and growth has been increased much less although some progress is achieved (Havranek and Benecke 1978; Reed et al. 1983; Flaig and Mohr 1990; Tognetti et al. 1994; Madsen 1995; Gerhardt 1996; Khan et al. 1996; van Hees 1997; Ammer 2002; Machado et al. 2003). In order to overcome the problem of how to get sound data of the belowground resource availability for individual seedlings, research on belowground resources has often been carried out under laboratory conditions but only rarely in the field. This is due to the fact that laboratory experiments provide the possibility to distinguish the effects of belowground resource availability on plant performance from aboveground factors like the PAR. Such a distinction is, however, much harder to achieve under natural conditions. Field research on the interactions between PAR and belowground resources and their effect on tree seedling growth are therefore a challenging and inspiring task. However, up to now the few investigations on this subject revealed contradicting results (Canham et al. 1996; Walters and Reich 1997; Finzi and
Canham 2000; Drever and Lertzman 2001; Aranda et al. 2002; Machado et al. 2003; van Hees and Clerkx 2003; Ricard et al. 2003; Sack 2004).

An elegant method to avoid laborious field measurements when assessing belowground resource availability has been reported by Kuuluvainen and Pukkala (1989). These authors calculated the amount of overstorey tree roots and used the calculated data for the evaluation of the abundance of Scots pine seedlings. The concept behind this approach is deduced from the "ecological field theory" which was developed by Wu et al. (1985). It takes the finding into account, that the amount of overstorey tree fine root biomass is related to soil moisture (Gerhardt 1996; Ammer 2002). In fact Ammer and Wagner (2002) and Lee et al. (2004) have shown that it is possible to predict the fine root biomass of mature trees by the application of tree root distribution models. Such model approaches take advantage from the fact that in contrast to radiation availability on the forest floor, belowground resources are affected more or less radialsymmetrically from the tree trunk (Wu et al. 1985), whereas light availability is influenced by a single tree heterogeneously in respect to azimuth directions on the northern hemisphere. Seedling growth may therefore be modelled using a combination of real resource information (e.g. PAR) and a surrogate for belowground resource availability of seedlings (Wagner 1999; Ammer et al. 2008).

Against this background the main objective of the present study was to test whether such a model which combines measured data of the aboveground resource PAR with data on the belowground resource availability derived by a fine root distribution model, yields better or equal results than explaining seedling growth by classic competition indices reflecting limited growing space. For this purpose we (1) derived a model for the height growth of beech seedlings in a factorial experiment which combines the resources light and soil moisture. Data from this experiment was used to find an appropriate combination of the functions describing the relationship between light and growth and soil moisture and growth. We then (2) tried to answer the question whether the derived method of a multiplicative combined factor model is also suitable to model height growth of naturally regenerated beech seedlings under the canopy of overstorey mature beech.

\section{Methods}

Experimental designs

\section{Controlled factorial experiment}

The experiment was carried out on farmland in 1990-1991 at the Højbakkegaard agricultural experimental station 
$20 \mathrm{~km}$ west of Copenhagen, Denmark. A two-factorial split-plot design randomized in two blocks was used with light, i.e. "relative PAR" (see "PAR-measurements") as the whole-plot factor and soil moisture, i.e. "SW" as the sub-plot factor. Each of the two factors was regulated to four levels making a total of 16 different treatments. In total this experiment comprised 32 containers.

May 1st 199015 beech nuts were sown in each of the 201 containers $(40 \mathrm{~cm}$ tall and diameter $25 \mathrm{~cm}$ ). When all seedlings had emerged they were randomly thinned to seven seedlings in each container. The growth medium of each container was 181 of homogenized soil, which originated from a A-horizon of a 139-years old beech stand (18\% clay and base saturation $37 \%$ ).

Shading curtains were placed by June 2nd (3 weeks after seedling emergence) to regulate the relative light intensity to $3,10,30$ and $65 \%$ in the four light treatments.

The experiment was located at an experimental area, which was automatically covered by a glass roof during rain. Additionally, irrigation and soil moisture measurements were carried out to control the soil moisture treatments. Madsen $(1994,1995)$ has described the experiment in greater detail.

\section{Field experiment}

Six gaps of $20-30 \mathrm{~m}$ diameter in a 110 -year old 15 ha beech stand were created in March 1988 succeeding a light beech mast in October 1987. European beech (Fagus sylvatica L.) accounts for $88.9 \%$ of the basal area and $91 \%$ of tree number of that stand. The top height of the overstorey beech trees was $33 \mathrm{~m}$. The stand is located in the forest district Göttinger Wald, Lower Saxony, Germany $\left(51^{\circ} 30^{\prime} \mathrm{N}, 9^{\circ} 48^{\prime} \mathrm{E} ; 310 \mathrm{~m}\right.$ elevation). The soil is calcareous limestone bedrock topped by a fairly heterogeneous loess cover. The loess cover extents $0-40 \mathrm{~cm}$ in height giving $\mathrm{pH}$ $(\mathrm{KCl})$ values of the soil from 6.5 to 4.5 depending on the thickness of the layer which is correlated to base saturation values between 90 and 50\% (Meiwes and Beese 1988). The humus layer is classified as F-Mull. Precipitation reaches $680 \mathrm{~mm}$ a year, $340 \mathrm{~mm}$ falls from May to September; summer drought can be observed occasionally. The mean temperature from May to September is $14^{\circ} \mathrm{C}$.

After the cuttings the entire area was fenced immediately and sample units of $0.5 \mathrm{~m}^{2}$ were established on the gaps and in the surrounding stand to perform regeneration measurements. In each gap 20 sample units were located in the northern, eastern, western and southern part of the gap as well as in the middle of the gap. Four sample units were placed in the closed stand, southward to each corresponding gap.

Germination of beech seedlings took place in spring 1988 and the seedlings grew up without any weed control.
Thus the true radiation environment of a particular seedling changed from year to year depending on its height relationship to the surrounding vegetation (Jobidon 1994). However, it is not known to what extent the ground vegetation affected soil water availability as well. At the end of the third vegetation period the height (in millimetres) of each seedling was measured and the radiation level above each sample unit related to open field conditions was assessed by means of hemispherical photography (see "PAR-measurements").

Data collection

\section{PAR-measurements}

"Photosynthetically active radiation" is a wavelength range (400-700 nm). However, for ease of writing in this paper "relative $P A R$ " is understood as the relative radiation intensity at $400-700 \mathrm{~nm}$ wavebands $\left(\mu \mathrm{mol} \mathrm{m} \mathrm{m}^{-2} \mathrm{~s}^{-1}\right)$ measured at the forest floor in relation to the radiation intensity at 400-700 $\mathrm{nm}$ wavebands above canopy.

(1) Measurements in the factorial experiment

A LI-COR Quantum Sensor placed below and above the curtains determined the light levels below the shading curtains.

\section{(2) Measurements in the field}

Above every sample unit on the experimental area a hemispherical photography was taken under overcast conditions (obscured overcast sky condition-sensu Grant et al. 1996) with a Canon ${ }^{\circledR} \mathrm{AE}-1$ camera and a Canon $7.5 \mathrm{~mm}, \mathrm{f} / 5.6$ lens on an AGFA ${ }^{\circledR}$-ORTHO film. The zenith luminance was measured in advance within an angle of view of $5^{\circ}$ (Wagner 1994, 1998; Clearwater et al. 1999); three stops of over-exposure were established. A photograph of an optical density wedge was taken on each film, allowing establishing film density function in the lab. With the method proposed by Wagner (1998) the photographs were analysed using the professional imaging software OPTIMAS ${ }^{\circledR}$. The method has been proven to yield very high degree of accuracy (Wagner 1996) as, e.g. penumbra effects can be taken into account. The method allows for corrections of vignetting of the lens as well as for heterogeneous luminance distribution of an overcast sky (Wagner 2001).

"Relative PAR" in relation to open field was computed assuming $60 \%$ of overcast conditions and $40 \%$ of clear sky conditions (clear sky condition-sensu Grant et al. 1996) within the vegetation period (Biederbick 1992). This relative radiation value was considered to be representative to all seedlings on that particular sample unit. However, this individual seedlings radiation level cannot 
be interpreted as equal for succeeding years. Thus it is not straightforward to relate the total height of the seedlings simply to the measured radiation level. Instead, individual height at the end of the fourth vegetation period was measured and the RGR of seedling height was calculated as:

$p=\left(H_{t}+1-H_{t}\right) / H_{t}$

with " $p$ " as the RGR, " $H$ " the height value and " $t$ " year.

Assessment of below ground resources and indices indicating limited growing space

Several different approaches were applied to estimate the intensity of factors important for the growth of beech seedlings besides relative PAR. Key variables chosen in this regard are below ground resource availability on the one hand and growing space on the other hand.

The belowground resource was directly measured in the factorial experiment, i.e. soil moisture. In the field experiment it was statistically derived by using a proxy: the modelled overstorey trees' root density. The latter approach is statistic by nature and has to be distinguished from models that are based on eco-physiological processes at the process level (e.g. Rötzer et al. 2008; Gayler et al. 2006; Zhang et al. 2006). Growing space was computed by classical position dependent competition indices algorithms.

\section{(1) Assessment of below ground resources}

Measurement of soil moisture in the factorial experiment: The target levels of soil moisture were 100, 80, 60 and $40 \%$ of field capacity in the bottom $14-28 \mathrm{~cm}$ of the containers, which was equivalent to 34.0, 27.2, 20.4 and 13.6 vol.\% soil water content-further referred to as "SW." The soil moisture measurements were carried out by TDR technique (Topp et al. 1980; Rundell and Jarrel 1991) in $0-14 \mathrm{~cm}$ and $0-28 \mathrm{~cm}$ depth before irrigation, which was carried out weekly in the growing seasons. The soil moisture data made it possible to calculate the soil moisture in $14-28 \mathrm{~cm}$ depth and the amount of water necessary to reach the target moisture in $14-28 \mathrm{~cm}$ depth of each container.

Assessments in the field: Overstorey trees root density was derived from a fine root distribution model for beech. Fine root intensity of overstorey trees was estimated for each sample unit by a model developed by Nielsen and Mackenthun (1991). The model follows Wu et al. (1985) who suggested models reflecting "ecological fields" of overstorey tree roots which do not consider patchiness of root systems but which assume that tree roots are distributed simply distance dependent and radialsymmetrical to the tree trunk. This is particularly important belowground, where fine root distribution and the effects on water and nutrient resources are spatially tightly coupled while in contrast aboveground radiation effects can be measured far away from leaves. The model of Nielsen and Mackenthun (1991) predicts the amount of fine root $(\leq 2 \mathrm{~mm}$ in diameter) in a zone of $45 \mathrm{~cm}$ soil depth per area soil surface $(\mathrm{mg}$ dry weight per $\mathrm{cm}^{2}$ soil surface) by the following equation:

$\operatorname{RIS}(\mathrm{dbh}$, dist $)=\left[A\left((\mathrm{dbh} / 2)^{2} \pi\right)^{D}\right] /[1+B \exp (C$ dist $)]$

where "RIS" is the root intensity of a single tree, "dbh" is its diameter at breast height in decimetre, "dist" is the distance from the point of interest to the middle of the tree trunk in centimetres and $\mathrm{A}, \mathrm{B}, \mathrm{C}$ and $\mathrm{D}$ are parameters of the model which are taken from Wagner (1999; $A=7.38$, $B=0.223, C=0.00825, D=0.573$ ) for beech in a mixed stand. With these parameter values the root intensity declines monotonously with increasing distance to the trees trunk. The computed root intensity of this model depends on the diameter of the tree and is supposed to diminish further away from the trees trunk than $7 \mathrm{~m}$. Based on this equation the amount of fine root biomass at a given point was computed by summing up the calculated fine root biomasses of all neighbouring trees at this point. Hence it is assumed that the total amount of fine roots at a given point results from additive contributions of the surrounding trees, located $<7 \mathrm{~m}$ from the point of interest. No interactions between tree roots are taken into account (Nielsen and Mackenthun 1991). This results in:

$\mathrm{RI}=\sum_{i=1}^{n} \mathrm{RIS}_{\mathrm{i}}$

where "RI" is the total root intensity in a particular spot and "RIS ${ }_{i}$ " is the contribution of the $\mathrm{i}$-th tree to that total. All surrounding trees which contributed to the root intensity were considered.

The value of this index is highest when the amount of overstorey fine root estimated is maximal (RI). As the scales of different indices are different, a normalisation was performed as follows:

$\mathrm{IRI}=1-\frac{\mathrm{RI}}{\mathrm{RI}_{(\max )}}$

with " $R I_{(\max )}$ " as the maximum value of the index in that particular stand and "IRI" as the inverse root intensity. The statistically derived root density of overstorey trees is nothing else but a belowground position dependent competition index.

(2) Indices indicating limited growing space based on aboveground information 
As outlined in the introduction height growth of beech seedlings was analysed by using common indices indicating growing space as independent variables $\left(\mathrm{CI}_{1}\right.$ to $\mathrm{CI}_{3}$ ).

$\mathrm{CI}_{1}$ is an adaptation of the competition index of Hegyi (1974):

$\mathrm{CI}_{1}=\sum_{j=1}^{n} \frac{\mathrm{dbh}_{j}}{\mathrm{dist}_{i j}}$

where $j$ represents the overstorey trees within a virtual reverse cone according to Pretzsch et al. (2002). For the determination of the overstorey trees within the cone, its vertex was assumed to be perpendicular to the position of each seedling. The angle which defines the width of the cone was $60^{\circ}$. The index itself is calculated by the sum of the diameters in breast height (dbh) of all selected overstorey trees divided by their distance to the subject seedling $i$.

$\mathrm{CI}_{2}$ represents the competition index of Pukkala and Kolström (1987)

$\mathrm{CI}_{2}=\sum_{j=1}^{n} \alpha_{j}$

where $j$ represents the overstorey trees determined as for $\mathrm{CI}_{1}$. The index is calculated by the sum of the angles which result by the virtual tangents from the subject tree seedling position in $1.3 \mathrm{~m}$ height to the each overstorey tree which laterally touch the stem in the same height.

$\mathrm{CI}_{3}$ represents an index according to El Kateb (1991):

$\mathrm{CI}_{3}=\frac{N^{2}}{b a}$

for the calculation of this index the overstorey trees are also determined as for $\mathrm{CI}_{1}$. The index is the ratio of the square of overstorey tree number $(N)$ and the corresponding basal area $(b a)$.

Modifications of these indices where tested in addition. This means that we used a cone width of $90^{\circ}$ and a radius of $15 \mathrm{~m}$ around the subject tree seedling for the identification of relevant overstorey trees. However, both modifications led to nearly identical results (not shown).

The values of all indices are highest when growing space is minimal. As the scales of the different indices are different, a normalisation was performed as follows:

$\mathrm{ICI}_{i}=1-\frac{\mathrm{CI}_{i}}{\mathrm{CI}_{i \max }}$

with " $\mathrm{CI}_{\text {max }}$ " as the maximum value of the index " $i$ " in that particular stand and " $\mathrm{ICI}_{i}$ " as the inverse value of that competition index " $i$ ".
Data evaluation

In this study two single factor models were applied:

(1) following Drever and Lertzman (2001) and Lin et al. (2002) the Michaelis-Menten function was applied in the case of relative PAR and (2) the Mitscherlich function was applied in all other factors, i.e. $S W$, IRI and $I C I$. These models were either applied as single factor models or as combined models based on single factors each. The combination of two factors was modelled by a multiplicative approach (see, e.g. Tilman 1982; Reed et al. 1983). Thus, taking the combination of relative $P A R$ and $S W$, the following equations were applied to predict the height growth of a seedling:

$\Delta H=H p(\mathrm{PAR}, \mathrm{SW})$

where

$$
\begin{aligned}
p(\mathrm{PAR}, \mathrm{SW})= & A[(\mathrm{PAR}-B) /((A / C)+(\mathrm{PAR}-B))] \\
& \times\left[(1-\exp (-\mathrm{DSW}))^{2}\right]
\end{aligned}
$$

" $\Delta H$ " refers to height growth of a subject seedling in a given year with height " $H$ " in the previous year, " $p$ " is the relative growth rate (RGR) of that individual plant in the current year, depending on the specific conditions, e.g. radiation and soil water in the environment of the subject seedling represented by the availability of the resources relative PAR and SW in the previous year. Likewise we tested the effect of relative PAR and IRI instead of relative PAR and SW. The parameters were estimated by use of Eq. 9 and standard non-linear regression technique (SPSS 12.0). To test whether the height growth of the seedlings was significantly depending on both, relative PAR and additional factors, a stepwise approach was used. First, significance of bivariate correlation between relative $P A R$ and the relative height growth value was tested. Second, the Michaelis-Menten function was parameterized with relative $P A R$ as the only independent variable. Third, the bivariate correlation between the residuals resulting from this parameterization and the additional factor was computed and tested for significance. Finally, the two-factor function (Eq. 10) was applied if the previously mentioned correlation revealed to be significant. As independence between the two "explaining" variables is a prerequisite for application of the two-factor model we observed the correlations carefully, e.g. evaluated bivariate correlation coefficients between the two independent variables. 
(2) Models using indices of growing space availability We took the general relation

$\Delta H=H p\left(\mathrm{ICI}_{\mathrm{i}}\right)$

and

$$
P\left(\mathrm{ICI}_{\mathrm{i}}\right)=A\left[\left(1-\exp \left(-\mathrm{DICI}_{\mathrm{i}}\right)\right)^{2}\right]
$$

using the Mitscherlich function where " $A$ " represents the asymptotic RGR and " $D$ " is a scaling factor for the index in regard.

\section{Results}

\section{Controlled factorial experiment}

The relevance of relative PAR to the relative height growth rate (" $p$ ") is obvious as is the relevance of soil moisture (SW) to the residuals of the pure relative PAR model (Table 1). There was no significant correlation between relative PAR and $S W$ (Table 1).

The application of the combined resource use model (Eq. 10) to the measured growth rates of the single trees yielded the parameter estimates given in Table 2 for the factorial experiment. From this an asymptote value for the 2-year-old beeches of more than $200 \%$ relative height growth rate can be taken $(A=2.31)$. This means that 1 year-old beech seedlings might triple height in the second growth season if the conditions, i.e. resource availability are optimal. In addition the goodness of fit is shown in Fig. 1 and in Table 2 (seventh column). Thus 54\% of the observed variation in individual tree height growth could be explained by a model which combines information on light and soil moisture and integrate these resources within a multiplicative growth function. Figure 1 provides information on the residuals of the height growth model with respect to the two independent variables relative $P A R$ and SW. Relative $P A R$ and $\mathrm{SW}$ were not correlated to the residuals of the combined resource model of Eq. 10 (Table 1). Merely the residuals of the model with respect to seedlings height of the previous year were not as evenly distributed as for the two resources (Fig. 1).

Field experiment

As the model used in "Controlled factorial experiment" revealed reasonable results we tested the combined resource model for the prediction of beech seedling in the field. The analysis of the field data showed a significant relationship between relative $P A R$ and the relative height growth rate (" $p$ ") of the seedlings (Table 1) which is comparable to the controlled factorial experiment. Moreover, applying the one-resource use model based on relative $P A R, I R I$ showed significant correlations to the residuals (Table 1). This means that IRI provides additional information which could be used modeling combined resources as shown in Eqs. 9 and 10. In contrast to the factorial experiment however, there is an albeit weak but significant correlation between relative $P A R$ and $I R I$ (Table 1). Parameter estimates of the field experiment using relative PAR and IRI in a model of two combined resources are shown in Table 2 . The asymptote value for 4year-old beeches amounted to $48 \%$ relative height growth rate. This means that a 3-year-old beech would add nearly $50 \%$ of its actual height in the fourth growing season at maximum if conditions are optimal under the given conditions, i.e. if best resource availability in the field experiment is given. The goodness of fit, when using the full combined resource use model (Eq. 9), can be seen from Fig. 2 and Table 2 (seventh column). Nearly $50 \%$ of the variation in individual seedling height growth could be explained by the model (Table 2, column 7). Residual plots of the combined resource use model with respect to the three independent variables relative PAR, IRI and $h$ are presented in Fig. 2. It is evident from this figure and Table 1 that there is no significant correlation between the residuals and the three independent variables.

Table 1 Bivariate correlation coefficients for the two models based on one and two combined resources

\begin{tabular}{|c|c|c|c|}
\hline \multicolumn{2}{|l|}{ Factorial experiment } & \multicolumn{2}{|l|}{ Field experiment } \\
\hline \multicolumn{4}{|l|}{ One resource } \\
\hline Relative $P A R \Leftrightarrow p$ & $0.222 P=0.003$ & Relative $P A R \Leftrightarrow p$ & $0.175 P=0.000$ \\
\hline$S W \Leftrightarrow$ resid & $0.551 P=0.000$ & $I R I \Leftrightarrow$ resid & $0.121 P=0.008$ \\
\hline Relative $P A R \Leftrightarrow S W$ & $-0.073 P=0.287$ & Relative $P A R \Leftrightarrow$ IRI & $-0.129 P=0.005$ \\
\hline \multicolumn{4}{|l|}{ Two resources } \\
\hline Relative $P A R \Leftrightarrow$ resid & $0.033 P=0.667$ & Relative $P A R \Leftrightarrow$ resid & $-0.021 P=0.652$ \\
\hline$S W \Leftrightarrow$ resid & $-0.114 P=0.134$ & $I R I \Leftrightarrow$ resid & $-0.087 P=0.056$ \\
\hline$h \Leftrightarrow$ resid & $-0.276 P=0.000$ & $h \Leftrightarrow$ resid & $-0.046 P=0.311$ \\
\hline$N$ & 174 & & 482 \\
\hline
\end{tabular}


Table 2 Parameter estimates and asymptotic standard error values for the combined resource use model (Eq. 12)

\begin{tabular}{llllll}
\hline & $A$ & $B$ & $C$ & $D$ & $r^{2}$ \\
\hline Factorial experiment & $2.31 \pm 0.23$ & $338.4 \pm 98.2$ & 0.02 & $5.93 \pm 0.67$ & 174 \\
Field experiment & $0.48 \pm 0.03$ & $87.9 \pm 30.8$ & 0.02 & $3.52 \pm 0.55$ & 482 \\
\hline
\end{tabular}

The value of $\mathrm{C}$ was determined in advance
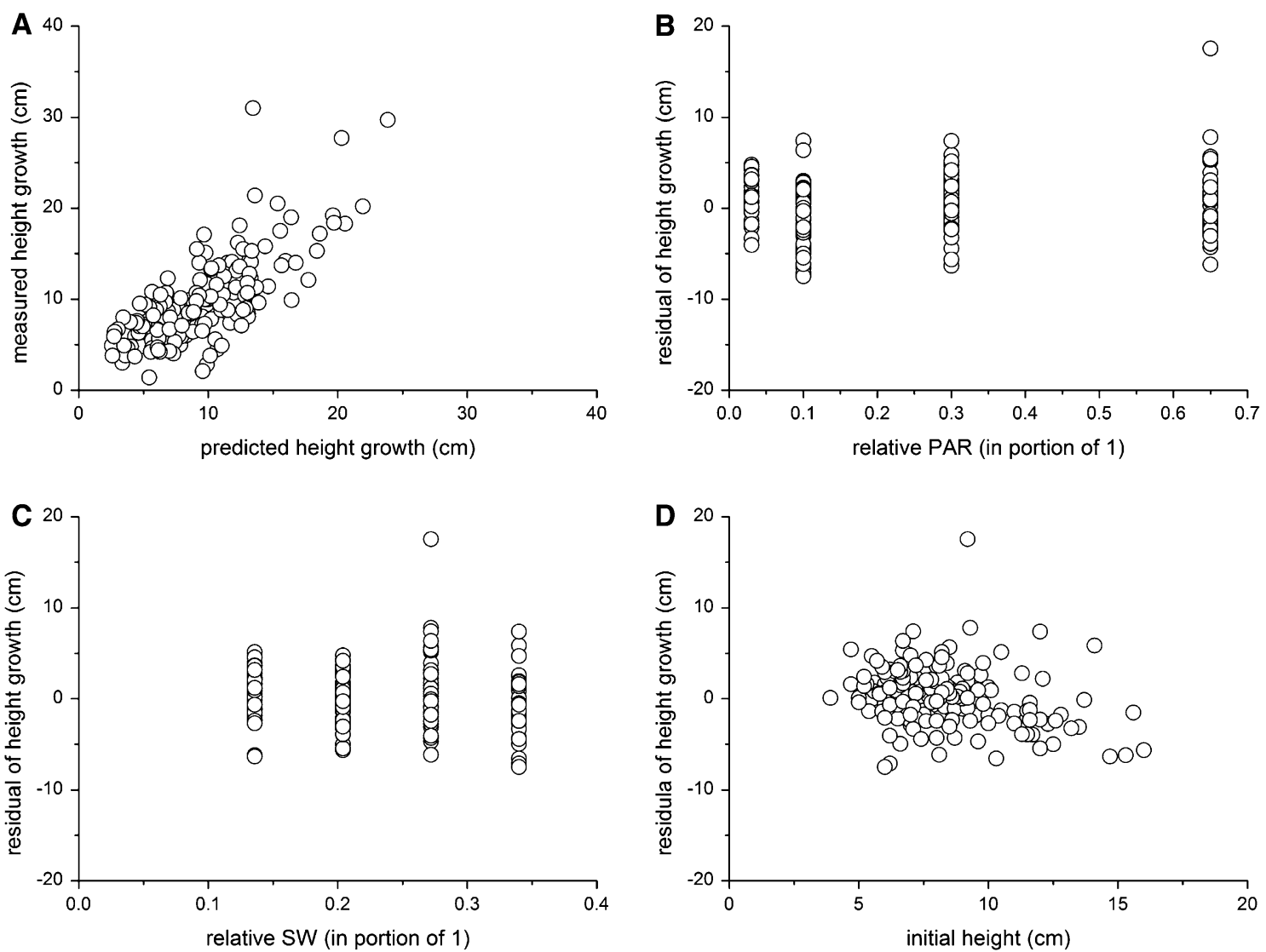

Fig. 1 Factorial experiment; goodness of fit of the combined resource use model and bisector (a) and the corresponding residuals in relation to relative PAR (b), soil moisture $(S W)(\mathbf{c})$ and initial height $(\mathbf{d})$

In addition to the resource based prediction of beech seedling growth a simple model using growing space availability expressed by several indices $\left(\mathrm{CI}_{1}\right.$ to $\left.\mathrm{CI}_{3}\right)$ was comparatively tested. This approach (Eq. 11) yielded the parameter estimates given in Table 3. It is evident that the differences between the indices in explaining beech seedling height growth are small. The best prediction of relative height growth showed index $\mathrm{CI}_{2}$ (Table 3; Fig. 3). Although the goodness of fit is satisfying (Fig. 3a) it seems that a slight bias is to be observed in so far, that neither the highest measured values are predicted very well nor are the lowest. Residuals of the growing space model (Eq. 12) taking index $\mathrm{CI}_{2}$ into account were neither significantly correlated to $\mathrm{ICI}_{2}$ nor to initial height (Fig. 3). However, residuals were correlated to relative PAR $(r=0.117$, $P=0.010)$. A look at the estimates of this index reveals an asymptote value for the investigated 4-year-old beech seedlings of approximately $42 \%$ relative height growth rate (Table 3). This means that a 3-year old beech would add around $40 \%$ of its actual height in the fourth growing season at maximum if the conditions are optimal.

\section{Discussion}

Is a model combining resource based growth functions suitable for the prediction of individual height growth of beech seedlings?

To answer the first question outlined in the introduction, we used existing data from the controlled factorial experiment. It is evident that both relative PAR and $S W$ 

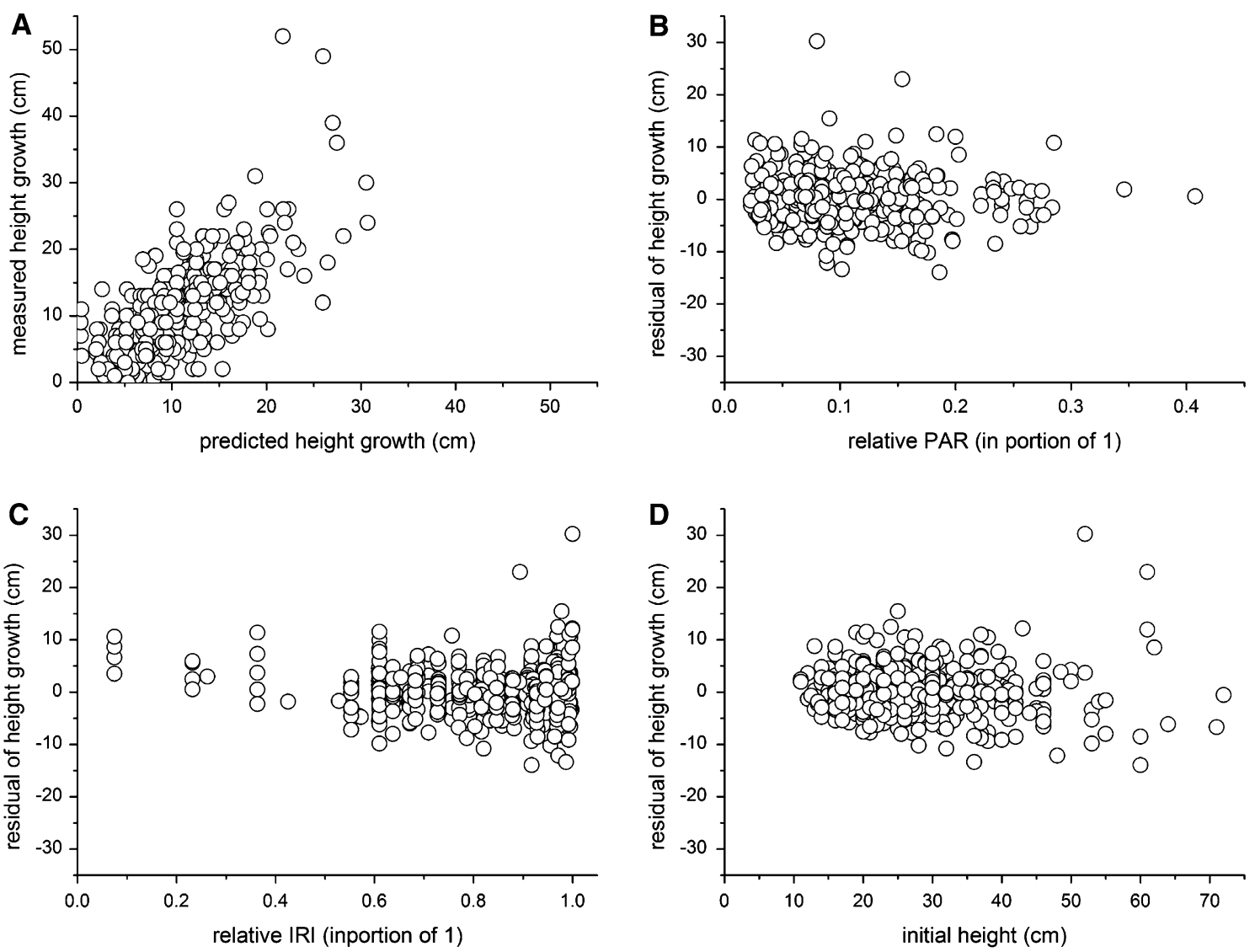

Fig. 2 Field experiment; goodness of fit of the combined resource use model and bisector (a) and the corresponding residuals in relation to relative PAR (b), IRI (c) and initial height $(\mathbf{d})$

are relevant resources for the height growth of beech seedlings (Tables 1, 2; Fig. 1). This finding is well known from previous studies (Burschel and Schmaltz 1965a; Tognetti et al. 1994; Madsen 1994, 1995; van Hees 1997; Collet et al. 2001, 2002; Ammer 2002). However, to our knowledge there exists no investigation where the appropriateness of a multiplicative approach of modelling relative $P A R$ and soil water effect on height growth of beech seedlings has been tested. Such an approach has so far merely been presented for a combination of growth functions for tree seedlings response to light and nitrogen supply by Reed et al. (1983). In general, as stated by Coomes and Grubb (2000) "little is known from experiments about the combined effects of water shortage and shade". It is therefore noticeable that the factorial experiment revealed not only the result that the availability of soil moisture strongly influences seedling growth under different radiation regimes, but also the suitability of a multiplicative approach for the reasonable combination of growth functions. However, applying the multiplicative approach to our data resulted in a systematic weakness of the model in predicting height growth if high radiation availability was combined with poor water
Table 3 Parameter estimates and asymptotic standard error values for the growing space model

\begin{tabular}{lllll}
\hline Index & $A$ & $D$ & $N$ & $r^{2}$ \\
\hline $\mathrm{CI}_{1}$ & $0.405 \pm 0.012$ & $7.570 \pm 2.620$ & 482 & 0.474 \\
$\mathrm{CI}_{2}$ & $0.416 \pm 0.015$ & $5.152 \pm 1.146$ & 482 & 0.478 \\
$\mathrm{CI}_{3}$ & $0.419 \pm 0.012$ & $6.157 \pm 1.220$ & 482 & 0.476 \\
\hline
\end{tabular}

supply (Fig. 4). These conditions led to an extreme low increment which is contradicted by the idea of stable asymptotic relative PAR reaction of the plants over the whole range of soil moisture (Sack 2004). Nevertheless, the combined resource use model approach presented here offers the opportunity to investigate the independent multiplicative effect of irradiance and water supply combinations on woody species as suggested by Sack and Grubb (2002). Thus, the applicability of a combined resource use model was proven successfully in height growth modelling of beech (Table 1; Fig. 1).

While the growth of the seedlings in this experiment was not restricted by nutrient availability (Madsen 1994) the only belowground factor modified within the experiment 

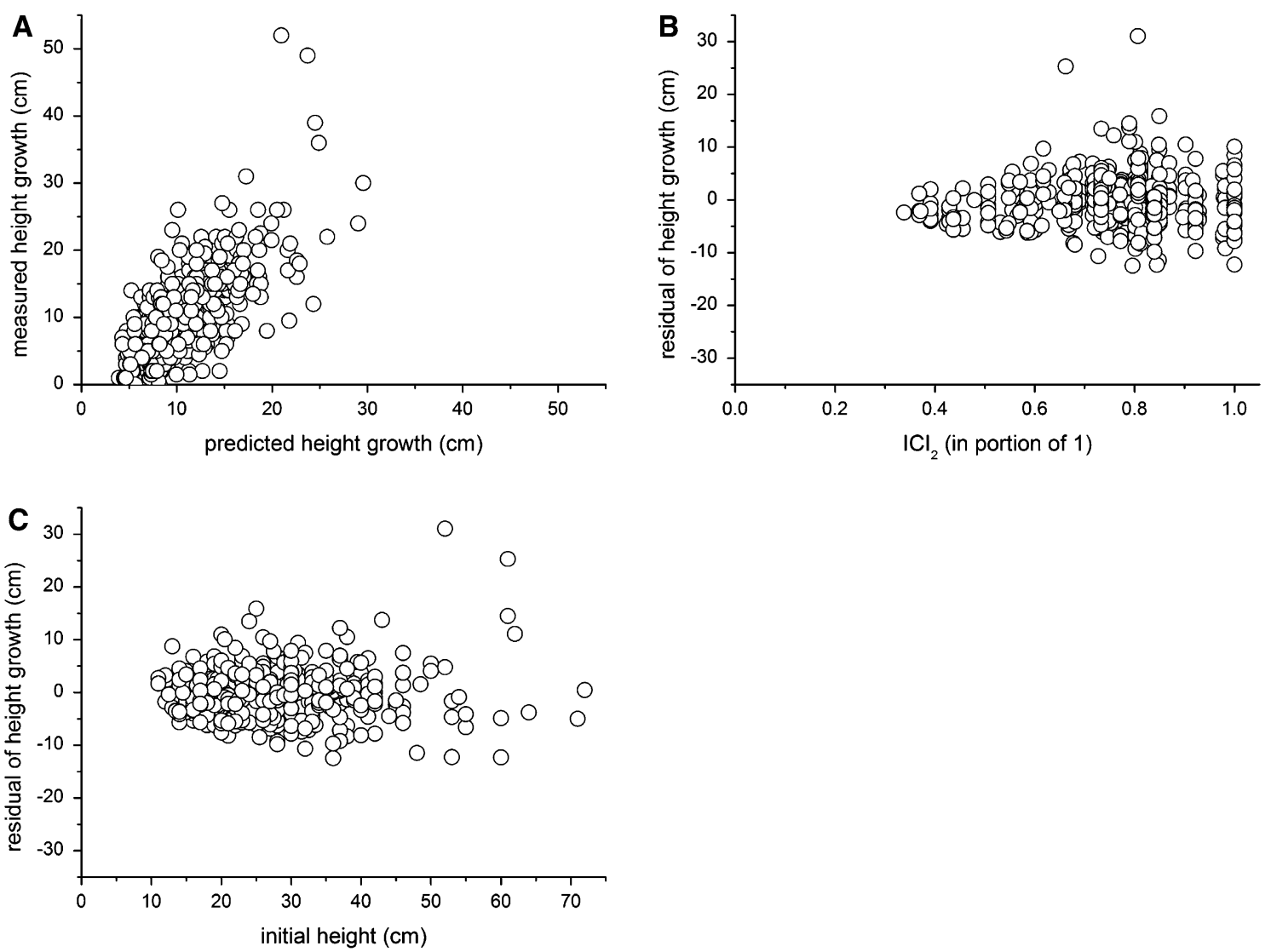

Fig. 3 Field experiment; goodness of fit of the index based model and bisector (a) and the corresponding residuals in relation to $\mathrm{ICI}_{2}(\mathbf{b})$ and initial height (c)

was water supply. As a consequence the parameterisation of the combined resource use model should yield parameter values of the Michaelis-Menten portion ("B" and "C") for true relative $P A R$ response. This means that without belowground resource constraints this parameterisation should hold true and should therefore be considered "pure relative PAR dependent" (Shainsky and Radosevich 1991; Mou and Fahey 1993).

Is it possible to predict individual height growth of beech seedlings in the field by a model which combines measured (light) and estimated (belowground resources) resource availability?

Against the background of the results of the factorial experiment and the physiological plausibility of combined resource use models (Smith and Huston 1989; Holmgren et al. 1997; Battaglia et al. 2000) it was expected that the chosen approach is also suitable to parameterise field data. As in the factorial experiment, water and not nutrients was likely to be the limiting belowground resource in the field experiment. This assumption is based on site characteristics like the $\mathrm{pH}(\mathrm{KCl})$ values of the soil, which range from 6.5 to 4.5 and the fact that the humus layer was classified as FMull. Ignoring the fact that there was a weak correlation between relative PAR and IRI (Table 1, fourth column) which will be discussed in the following, the multiplicative approach yielded satisfying results also for the field data (Table 2; Fig. 2).

Separating the effect of light and belowground resources in the field requires a broad range of values of both variables. To distinguish between the effects of relative PAR and a radial symmetric belowground resource within one experiment it is necessary to minimize the correlation between these two resources. This can experimentally be achieved by gap creation. In higher latitude on the northern hemisphere a high relative PAR-intensity on the northern edge of a gap and a low relative PAR-intensity on the southern part of a gap can be found (Canham et al. 1990). In contrast to relative PAR, assuming a distance dependency of fine root density distribution (Ammer and Wagner 2005; Zerihun et al. 2007), root density is constant in a particular distance to the gap edge (Brockway and Outcalt 1998; Ammer and Wagner 2002; Müller and Wagner 2003). However, while in the controlled factorial experiment no significant correlation between relative PAR and 


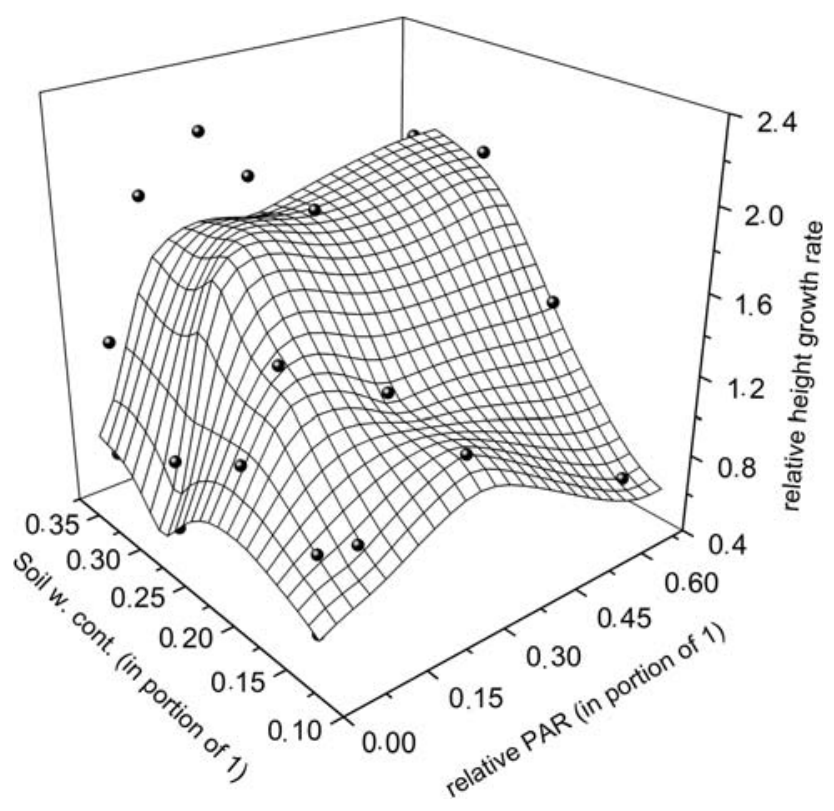

Fig. 4 Three-dimensional surface plot of radiation (relative PAR in portion of 1) and water (soil water content in portion of 1) impact on relative length growth rate of beech seedlings in the factorial experiment. Open and solid dots show values of the relative growth rate of each of the two plots per factor combination. The surface is computed by local linear regression. The low rlgr-value at relative $\mathrm{PAR}=0.6$ and $\mathrm{SW}=0.15$ is commented in the discussion

SW values was observed, a weak but significant correlation was given in the field experiment between relative PAR and IRI although we carried out the investigation using gaps.

Beside the independency of above- and belowground resources, the detection of resource effects on seedling growth is facilitated by a high variation of the resource in regard. This means that for example investigations which failed to identify a significant impact of soil moisture status on seedling growth (Burschel and Schmaltz 1965b; Pacala et al. 1994) presumably did not provide a resource variation which was high enough to do so. The stand investigated here matches the requirement of high water resource variability in so far that steep gradients of soil moisture availability were likely to occur in stands with large gaps and shallow soils. In such stands the variety of stand densities ranges from gaps to closed stand sections. The assumption that a high variation of soil moisture can be found in heterogeneously stocked mature stands was recently confirmed by Ammer and Wagner (2002). Like relative $P A R$ which is attenuated by overstorey trees to very low light levels [in beech forests down to $2 \%$ compared to open field conditions (Larcher 1994; Mayer et al. 2002)] overstories can also drastically reduce soil moisture available for seedlings (Aranda et al. 2002). The idea of stand density as being a steering feature to soil water supply for seedlings is supported by work of Riegel et al.

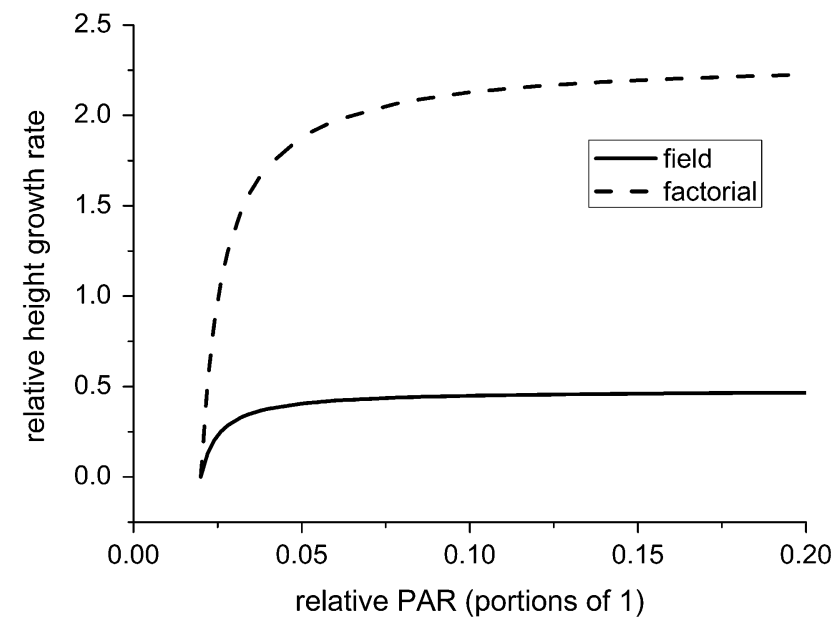

Fig. 5 Model function graphs of predicted relative height growth rate in relation to relative PAR (Michaelis-Menten portion for true relative PAR response of combined resource use model, Eq. 10) for the factorial experiment (dashed line) and the field experiment (solid line)

(1995), Walters and Reich (1997) and Coomes and Grubb (2000) who pointed out the distinct relationship between fine root mass and soil moisture and nutrient availability. Belowground resource availability is therefore supposed to be inversely related to the fine root intensity of overstorey trees. Based on this idea, which was promoted by Wu et al. (1985), we used IRI as a rough estimator for soil moisture availability. In fact Ammer and Wagner (2002) could show that fine root biomass predicted by models which integrate information about tree dimension and spatial distribution is correlated to soil moisture. Moreover, Ammer et al. (2008) recently showed that modelled fine root biomass of overstorey trees could partly explain variation in early seedling growth. Indeed the goodness of fit of the combined resource use model was fairly satisfying and the residuals were well balanced (Fig. 2).

Because IRI is radial symmetric, the parameterisation of the combined resource use model should yield parameter values of the Michaelis-Menten portion ("B" and "C") for true relative PAR response. The parameterisation should therefore hold true without belowground resource constraints. As hypothesised in the introduction it should be considered "pure relative PAR dependent" and parameters should be comparable to those of the factorial experiment.

Looking at the pure relative PAR response of the relative height growth of beech seedlings of both experiments in Fig. 5, two features are obvious: the two beech cohorts differ markedly in the value of the asymptotic RGR given unlimited relative PAR supply (2.3 versus 0.45$)$ and the curves both pass through their steepest portions when relative PAR supply is $<10 \%$. Both features lead to almost identical curves when the ratio of the two asymptote values is taken as a factor for the conversion of one curve into the 
other. In other words: if the Michaelis-Menten function parameterised for the 4-year-old beeches of the field experiment is multiplied with a value of 4.8 (ratio 2.31 to 0.48 , the values of the parameter " $\mathrm{A}$ " in Table 2) a function results which is fairly the same than the one resulting from the parameterisation for the 2-year-old beeches of the factorial experiment. Thus, the Michaelis-Menten function of one experiment can simply be converted to the Michaelis-Menten function of the other experiment by multiplication with a constant. This finding is important in regard to parameterisation techniques for regeneration models in so far that a complete parameterised light response curve from controlled conditions (e.g. in the lab) might be taken to field data. Thus, parameter estimates will be more confident allowing for reduction of parameters to be estimated from field data, i.e. instead of three parameters of Michaelis-Menten function only one is necessary (asymptote).

However, the different value of the asymptote ("A") cannot fully be explained by the availability of relative $P A R$. Keeping in mind that the RGR is supposed to be (1) determined by endogen plant properties (e.g. age: Wenk et al. 1990; Ammer et al. 2004) and (2) by environmental properties (e.g. availability of resources: Thomas and Weiner 1989) and that soil moisture availability or belowground competition by overstorey tree roots was implemented in the models, only endogen plant properties remain as explaining variables for the different asymptotic values of the two growth functions.

In growth and yield research several functions have been developed to describe the age effect on RGR assuming no resource limitations, e.g. open field conditions (see Wenk et al. 1990; Weiner and Thomas 2001). These functions follow the assumption of a more or less steep decline of the RGR within the first years. Thus, the difference in the RGR level (value of the asymptote) between the two experiments might simply be explained by differences in age or initial height of the beeches. While a 1-year old $8 \mathrm{~cm}$ tall beech seedling in the factorial experiment yielded $9.6 \mathrm{~cm}$ height increment in the second year at average and a 1-year-old $11 \mathrm{~cm}$ tall beech seedling in the field experiment yielded $8.4 \mathrm{~cm}$ in the second year-both more than 0.7 RGR-a 3year old $27 \mathrm{~cm}$ tall beech seedling of the field experiment yielded only $10.7 \mathrm{~cm}$ height increment in the fourth year. This corresponds to a RGR of approximately 0.4 (Table 4). To yield the same RGR as the 1-year-old $11 \mathrm{~cm}$ tall seedling 3-year old $27 \mathrm{~cm}$ seedling would have had to grow $20 \mathrm{~cm}$ in the following year. In this phase of seedling development RGR values of the asymptote are thus not probable to stay constant over subsequent years (see second and third year in Table 4). This is in accordance to the findings of Brand (1986), Kneeshaw et al. (1998) and Ammer et al. (2004). In contrast to these authors Collet et al. (2002) could not find any effect of beech seedling age on any parameter of seedling growth. Another explanation for the differences in the true relative PAR-response of the two cohorts may be differing carry-over effects. As Löf and Welander (2000) pointed out biomass production of beech seedlings is influenced by previous year drought. In contrast to the seedlings of the factorial experiment the saplings of the field study could have been affected thereof.

Is a model based on a traditional index for growing space availability more suitable for the prediction of beech seedling's height growth than a resource based model?

A easy way to determine the effect of overstorey trees on seedlings is to use competition indices (Herling 2005). Such indices integrate the limitation of above- and belowground resource availability to a dimensionless value which increases which decreasing growing space. Many of these indices are distance dependent and radial symmetric (Bachmann 1998).

The results of the present study show that the variation of beech seedling's height growth which could be explained by either a model where the initial height and a competition index served as independent variables or by a model where initial height and above- and belowground resources were used as independent variables was more or less comparable (Table 3). Thus with both approaches approximately half of the observed variation in seedlings RGR could be explained. Note that the differences between the two approaches regarding the zone affected by an overstorey tree (radial symmetric in the case of the growing space indices, but radial symmetric (belowground resource availability) and radial asymmetric (relative PAR considering direct radiation) in the case of the combined resource use model) obviously did not influence the predictive ability of a model. However, qualitatively there is a big difference between the two concepts. While the growing space-index approach provides no information on the environmental factors constraining tree seedlings growth, the multiplicative combined resource model can be used to

Table 4 Mean height $(\mathrm{MH})$ and mean height increment (MHI) in cm; RGR in brackets

\begin{tabular}{llllllll}
\hline & MH, year 1 & MHI, year 2 & MH, year 2 & MHI, year 3 & MH, year 3 & MHI, year 4 & $N$ \\
\hline Factorial experiment & 8.28 & $9.60(1.16)$ & 17.88 & & & 174 \\
Field experiment & 11.05 & $8.37(0.76)$ & 19.42 & $7.72(0.40)$ & 27.14 & $10.68(0.39)$ & 482 \\
\hline
\end{tabular}


get a better understanding of growth dynamics in the field. In fact there is for example an ontogenetic variation in the relative influence of light and belowground resources in beech seedling growth (Ammer et al. 2008). In addition, we observed a slight bias in the simple competition index model (see Fig. 3a) which might be due to the lack of any relative PAR-information in this model. Taking the radial symmetrical character of the competition index into account it is possible that the beeches received less relative $P A R$ on the southern part of the gaps compared to western or eastern parts. This is not indicated by the any of the tested competition indices. This interpretation is in fairly good concordance with the less obvious bias in Fig. 2a, where relative $P A R$-information and the radial symmetrical root competition index are combined. However, only in the factorial experiment the model is free of any bias (Fig. 1a) indicating a problem of the field experiment which cannot be fully explained.

Comparing the different competition indices tested in our study it can be stated, that the type of the index and the underlying approach of selecting overstorey trees affecting growing space seem not to be very important for the amount of explained variation (Table 3).

\section{Conclusions}

The present study attempted to model the height growth of single beech seedlings in the field. According to Goldberg (1990) seedling growth is the response on resource availability determined by the presence and dimension of overstorey trees. Given a maximum RGR development over age, a stable RGR, i.e. a stable form of the response curve of a species to resource limitation within the years of seedling stage might be expected. This assumption is confirmed by the results of our study. Based on various physiological responses Aranda et al. (2002) demonstrated the high importance of the light/ water interactions for beech under canopies of different closure. Taking the findings of Aranda et al. (2002) and the results of the present study into account, it can be concluded that the combined resource use model approach is appropriate for modelling height growth of beech seedlings in the field by using an indirect method of estimating belowground resource availability. From a silvicultural point of view the application of such models is of great interest in order to get rough estimations of the growth potential of seedlings under given conditions. For this purpose however, models using competition indices which require only easy to measure data, are suitable as well. However, it might be helpful to develop competition indices which include belowground factors, especially when predicting seedling growth. Realistic predictions of height growth are for example important for controlling inter (tree) specific competition and weed interference and for planning partial-cutting treatments and predicting their long-term consequences (Drever and Lertzman 2001). Nevertheless, only the combined resource use model approach provides an improved ecophysiological understanding of seedling growth in the field. The implementation of the underlying functions into generalised models of forest productivity (e.g. Landsberg and Waring 1997) may be an option.

Open Access This article is distributed under the terms of the Creative Commons Attribution Noncommercial License which permits any noncommercial use, distribution, and reproduction in any medium, provided the original author(s) and source are credited.

\section{References}

Ammer C (2002) Response of Fagus sylvatica seedlings to root trenching of overstorey Picea abies. Scand J For Res 17:408416. doi:10.1080/028275802320435423

Ammer C (2003) Growth and biomass partitioning of Fagus sylvatica L. and Quercus robur L. seedlings in response to shading and small changes in the R/FR-ratio of radiation. Ann For Sci 60:163-171. doi:10.1051/forest:2003009

Ammer C, Wagner S (2002) Problems and options in modelling fine root biomass of single mature Norway spruce trees at given points from stand data. Can J For Res 32:581-590. doi:10.1139/ x01-229

Ammer C, Wagner S (2005) An approach for modelling the mean fine root biomass of Norway spruce stands. Trees (Berl) 19:145-153. doi:10.1007/s00468-004-0373-4

Ammer C, Brang P, Knoke T, Wagner S (2004) Methoden zur waldbaulichen Untersuchung von Jungwüchsen. Forstarchiv 75:83-110

Ammer C, Stimm B, Mosandl R (2008) Ontogenetic variation in the relative influence of light and belowground resources on European beech seedling growth. Tree Physiol 28:721-728

Aranda I, Gil L, Pardos JA (2002) Physiological responses of Fagus sylvatica L. seedlings under Pinus sylvestris L. and Quercus pyrenaica Willd. overstories. For Ecol Manage 162:153-164. doi:10.1016/S0378-1127(01)00502-3

Aussenac G (2000) Interactions between forest stands and microclimate: ecophysiological aspects and consequences for silviculture. Ann For Sci 57:287-301. doi:10.1051/forest:2000119

Bachmann M (1998) Indizes zur Erfassung der Konkurrenz von Einzelbäumen. Forstliche Forschungsberichte München No. 171, $235 \mathrm{pp}$

Battaglia LL, Foré SA, Sharitz RP (2000) Seedling emergence survival and size in relation to light and water availability in two bottomland hardwood species. J Ecol 88:1041-1050. doi: 10.1046/j.1365-2745.2000.00518.x

Beaudet M, Messier C (1998) Growth and morphological responses of yellow birch sugar maple and beech seedlings growing under a natural light gradient. Can J For Res 28:1007-1015. doi:10.1139/ cjfr-28-7-1007

Biederbick K-H (1992) Die direkte Sonnenstrahlung als Standortsfaktor. Forstarchiv 63:131-136

Brand DG (1986) A competition index for predicting the vigour of planted Douglas-fir in southwestern British Columbia. Can J For Res 16:23-29 
Brockway DG, Outcalt KW (1998) Gap-phase regeneration in longleaf pine wiregrass ecosystems. For Ecol Manage 106:125-139. doi:10.1016/S0378-1127(97)00308-3

Burschel P, Schmaltz J (1965a) Die Bedeutung des Lichts für die Entwicklung junger Buchen. Allg Forst J Ztg 136:193-210

Burschel P, Schmaltz J (1965b) Untersuchungen über die Bedeutung von Unkraut- und Altholzkonkurrenz für junge Buchen. Forstwiss Cbl 84:230-243. doi:10.1007/BF01872788

Canham CD, Denslow JS, Platt WJ, Runkle JR, Spies TA, White PS (1990) Light regimes beneath closed canopies and tree-fall gaps in temperate and tropical forests. Can J For Res 20:620-631. doi: 10.1139/x90-084

Canham CD, Berkowitz AR, Kelly VR, Lovett GM, Ollinger SV, Schnurr J (1996) Biomass allocation and multiple resource limitation in tree seedlings. Can J For Res 26:1521-1530. doi: $10.1139 / \times 26-171$

Chazdon RL, Field CB (1987) Photographic estimation of photosynthetically active radiation: evaluation of a computerized technique. Oecologia 73:525-532. doi:10.1007/BF00379411

Claveau Y, Messier C, Comeau PG, Coates KD (2002) Growth and crown morphological responses of boreal conifer seedlings and saplings with contrasting shade tolerance to a gradient of light and height. Can J For Res 32:458-468. doi:10.1139/x01-220

Clearwater MJ, Nifinluri T, van Gardingen PR (1999) Forest fire smoke and a test of hemispherical photography for predicting understorey light in Bornean tropical rain forest. Agric For Meteorol 97:129-139. doi:10.1016/S0168-1923(99)00058-1

Coates KD, Burton PJ (1999) Growth of planted tree seedlings in response to ambient light levels in northwestern interior cedarhemlock forests of British Columbia. Can J For Res 29:13741382. doi:10.1139/cjfr-29-9-1374

Collet C, Colin F, Bernier F (1997) Height growth shoot elongation and branch development of young Quercus petraea grown under different levels of resource availability. Ann Sci For 54:65-81. doi:10.1051/forest:19970106

Collet C, Lanter O, Pardos M (2001) Effects of canopy opening on height and diameter growth in naturally regenerated beech seedlings. Ann For Sci 58:127-134. doi:10.1051/forest:2001112

Collet C, Lanter O, Pardos M (2002) Effects of canopy opening on the morphology and anatomy of naturally regenerated beech seedlings. Trees (Berl) 16:291-298. doi:10.1007/s00468-0010159-x

Comeau PG, Braumandl TF, Xie C-Y (1993) Effects of overtopping vegetation on light availability and growth of Engelmann spruce (Picea engelmanii) seedlings. Can J For Res 23:2044-2048. doi: 10.1139/x93-255

Coomes DA, Grubb PJ (2000) Impacts of root competition in forests and woodlands: a theoretical framework and review of experiments. Ecol Monogr 70:171-207

Dohrenbusch A (1995) Überlegungen zur Optimierung der Strahlungsmessung im Wald. Allg Forst J Ztg 166:109-114

Drever CR, Lertzman KP (2001) Light-growth responses of coastal Douglas-fir and Western redcedar saplings under different regimes of soil moisture and nutrients. Can J For Res 31:2124 2133. doi:10.1139/cjfr-31-12-2124

El Kateb H (1991) Der Einfluss waldbaulicher Maßnahmen auf die Sprossgewichte von Naturverjüngungspflanzen im Bergmischwald. Forstl Forschungsberichte München Nr.111, 193 pp

Finzi AC, Canham CD (2000) Sapling growth in response to light and nitrogen availability in a southern New England forest. For Ecol Manage 131:153-165. doi:10.1016/S0378-1127(99)00206-6

Flaig H, Mohr H (1990) Auswirkungen eines erhöhten Ammoniumangebots auf die Keimpflanzen der gemeinen Kiefer (Pinus sylvestris L.). Allg Forst J Ztg 162:35-42

Gardiner ES, Hodges JD (1998) Growth and biomass distribution of cherrybark oak (Quercus padoga Raf.) seedlings as influenced by light availability. For Ecol Manage 108:127-134. doi: 10.1016/S0378-1127(98)00220-5

Gayler S, Grams TEE, Kozovits AR, Winkler JB, Luedemann G, Priesack E (2006) Analysis of competition effects in mono- and mixed cultures of juvenile beech and spruce by means of the plant growth simulation model PLATHO. Plant Biol 8:503-514. doi:10.1055/s-2006-923979

Gerhardt K (1996) Effects of root competition and canopy openness on survival and growth of tree seedlings in a tropical seasonal dry forest. For Ecol Manage 82:33-48. doi:10.1016/0378-1127 (95)03700-4

Goldberg DE (1990) Components of ressource competition in plant communities. In: Grace J, Tilman D (eds) Perspectives on plant competition. Academic, San Diego, pp 27-49

Grant RH, Heisler GM, Gao W (1996) Photosynthetically-active radiation: sky radiance distributions under clear and overcast conditions. Agric For Meteorol 82:267-292. doi:10.1016/01681923(95)02327-5

Grubb PJ, Lee WG, Kollmann J, Wilson JB (1996) Interaction of irradiance and soil nutrient supply on growth of seedlings of ten European tall-shrub species and Fagus sylvatica. J Ecol 84:827840. doi:10.2307/2960555

Havranek WM, Benecke U (1978) The influence of soil moisture on water potential transpiration and photosynthesis of conifer seedlings. Plant Soil 49:91-103. doi:10.1007/BF02149911

Hegyi F (1974) A simulation model for managing Jack-pine stands. In: Fries $\mathbf{J}$ (ed) Growth models for tree and stand simulation. Royal College of Forestry, Stockholm, pp 74-90

Herling H (2005) Integration von Verjüngung in Waldwachstumssimulatoren. Ph.D. thesis, Wissenschaftszentrum Weihenstephan, Technische Universität München, 294 pp

Holmgren M, Scheffer M, Huston M (1997) The interplay of facilitation and competition in plant communities. Ecology 78:1966-1975

Jobidon R (1994) Light threshold for optimal black spruce (Picea mariana) seedling growth and development under brush competition. Can J For Res 24:1629-1635. doi:10.1139/x94-211

Kaelke CM, Kruger EL, Reich PB (2001) Trade-offs in seedling survival, growth, and physiology among hardwood species of contrasting successional status along a light-availability gradient. Can J For Res 31:1602-1616

Khan SR, Rose R, Haase DL, Sabin TE (1996) Soil water stress: its effects on phenology physiology and morphology of containerized Douglas-fir seedlings. New For 12:19-39. doi:10.1007/ BF00029980

Kneeshaw D, Bergeron Y, De Grandpré L (1998) Early response of Abies balsamea seedlings to artificially created openings. J Veg Sci 9:543-550. doi:10.2307/3237270

Kneeshaw DD, Williams H, Nikinmaa E, Messier C (2002) Patterns of above- and below-ground response of understorey conifer release 6 years after partial cutting. Can J For Res 32:255-265. doi: $10.1139 / x 01-190$

Kuuluvainen T, Pukkala T (1989) Effect of Scots pine seed trees on the density of ground vegetation and tree seedlings. Silva Fenn 23:159-167

Landsberg JJ, Waring RH (1997) A generalised model of forest productivity using simplified concepts of radiation-use efficiency carbon balance and partitioning. For Ecol Manage 95:209-228. doi:10.1016/S0378-1127(97)00026-1

Larcher W (1994) Ökophysiologie der Pflanzen: Leben Leistung und Streßbewältigung der Pflanzen in ihrer Umwelt, 5th edn. Eugen Ulmer, Stuttgart

Lee EH, Tingey DT, Beedlow PA, Johnson MG, McKane RB (2004) A spatial analysis of fine-root biomass from stand data in the Pacific Northwest. Can J For Res 34:2169-2180. doi:10.1139/ x04-098 
Lin J, Harcombe PA, Fulton MR, Hall RW (2002) Sapling growth and survivorship as a function of light in a mesic forest of southeast Texas, USA. Oecologia 132:428-435. doi:10.1007/s00442-0020986-5

Löf M, Welander NT (2000) Carry-over effects on growth and transpiration in Fagus sylvatica seedlings after draught at various stages of development. Can J For Res 30:468-475. doi: 10.1139/cjfr-30-3-468

Machado J-L, Walters MB, Reich PB (2003) Below-ground resources limit seedling growth in forest understories but do not alter biomass distribution. Ann For Sci 60:319-330. doi:10.1051/ forest:2003023

Madsen P (1994) Growth and survival of Fagus sylvatica seedlings in relation to light intensity and soil water content. Scand J For Res 9:316-322. doi:10.1080/02827589409382846

Madsen P (1995) Effects of soil water content fertilization light weed competition and seedbed type on natural regeneration of beech (Fagus sylvatica). For Ecol Manage 72:251-264. doi:10.1016/ 0378-1127(95)97453-Y

Mayer H, Holst T, Schindler D (2002) Mikroklima in Buchenbeständen-Teil 1: Photosynthetisch aktive Strahlung. Forstw Cbl 121:301-321. doi:10.1046/j.1439-0337.2002.02038.x

Meiwes KJ, Beese F (1988) Ergebnisse der Untersuchung des Stoffhaushaltes eines Buchenwaldökosystems auf Kalkgestein. Berichte des Forschungszentrums Waldökosysteme (Göttingen) Reihe B Nr. 9, pp 1-45

Mou P, Fahey TJ (1993) Regrow: a computer model simulating the early successional process of a disturbed northern hardwood ecosystem. J Appl Ecol 30:676-688. doi:10.2307/2404246

Müller KH, Wagner S (2003) Fine root dynamics in gaps of Norway spruce stands in the German Ore mountains. Forestry 76:149158. doi:10.1093/forestry/76.2.149

Nielsen CNN, Mackenthun G (1991) Die horizontale Variation der Feinwurzelintensität in Waldböden in Abhängigkeit von der Bestockungsdichte. Allg Forst J Ztg 162:112-119

Oliver CD, Larson BC (1996) Forest stand dynamics. Wiley, New York

Pacala SW, Canham CD, Silander JA, Kobe RK (1994) Sapling growth as a function of resources in a north temperate forest. Can J For Res 24:2172-2183. doi:10.1139/x94-280

Pacala SW, Canham CD, Saponara J, Silander JA, Kobe RK, Ribbens E (1996) Forest models defined by field measurements: estimation error analysis and dynamics. Ecol Monogr 66:1-43. doi: $10.2307 / 2963479$

Pretzsch H, Biber P, Durský J (2002) The single tree-based stand simulator SILVA: construction application and evaluation. For Ecol Manage 162:3-21. doi:10.1016/S0378-1127(02)00047-6

Pukkala T, Kolström T (1987) Competition indices and the prediction of radial growth in Scots pine. Silva Fenn 21:55-67

Reed KL, Shumway JS, Walker RB, Bledsoe CS (1983) Evaluation of the interaction of two environmental factors affecting Douglasfir seedlig growth: light and nitrogen. For Sci 29:193-203

Ricard J-P, Messier C, Delagrange S, Beaudet M (2003) Do understory sapling respond to both light and below-ground competition: a field experiment in a north-eastern American hardwood forest and a literature review. Ann For Sci 60:749756. doi:10.1051/forest:2003069

Rich PM (1990) Characterizing plant canopies with hemispherical photographs. Remote Sens Rev 5:13-29

Riegel GM, Miller RF, Krueger WC (1995) The effects of aboveground and belowground competition on understory species composition in a Pinus ponderosa forest. For Sci 41:864-889

Rötzer T, Seifert T, Pretzsch H (2008) Modelling above and below ground carbon dynamics in a mixed beech and spruce stand influenced by climate. Eur J For Res. doi:10.1007/s10342008-0218-6
Rundell PW, Jarrel WM (1991) Water in the environment. In: Pearcy RW, Ehleringer J, Mooney HA, Rundell PW (eds) Plant physiological ecology. Chapman and Hall, London

Sack L (2004) Responses of temperate woody seedlings to shade and draught: do trade-offs limit potential niche differentiation? Oikos 107:110-127. doi:10.1111/j.0030-1299.2004.13184.x

Sack L, Grubb PJ (2002) The combined impacts of deep shade and draught on the growth and biomass allocation of shade-tolerant woody species. Oecologia 131:175-185. doi:10.1007/s00442002-0873-0

Shainsky LJ, Radosevich SR (1991) Analysis of yield-density relationships in experimental stands of Douglas-fir and Red Alder seedlings. For Sci 37:574-592

Smith T, Huston M (1989) A theory of the spatial and temporal dynamics of plant communities. Vegetatio 83:49-69. doi: 10.1007/BF00031680

Thomas SC, Weiner J (1989) Including competitive asymmetry in measures of local interference in plant populations. Oecologia 80:349-355. doi:10.1007/BF00379036

Tilman D (1982) Resource competition and community structure. Princeton University Press, Princeton

Tognetti R, Michelozzi M, Borghetti M (1994) Response to light of shade-grown beech seedlings subjected to different watering regimes. Tree Physiol 14:751-758

Topp GC, Davis JL, Annan AP (1980) Electromagnetic determination of soil water content: measurements in coaxial transmission lines. Water Resour Res 16:574-582

van Hees AFM (1997) Growth and morphology of pedunculate oak (Quercus robur L.) and beech (Fagus sylvatica L.) seedlings in relation to shading and draught. Ann Sci For 54:9-18. doi: 10.1051/forest: 19970102

van Hees AFM, Clerkx APPM (2003) Shading and root-shoot relations in saplings of silver birch pedunculate oak and beech. For Ecol Manage 176:439-448. doi:10.1016/S0378-1127(02) 00307-9

von Lüpke B (1987) Einflüsse von Altholzüberschirmung und Bodenvegetation auf das Wachstum junger Buchen und Traubeneichen. Forstarchiv 58:18-24

Wagner S (1994) Strahlungsschätzung in Wäldern durch hemisphärische Fotos-Methode und Anwendung. Berichte des Forschungszentrums Waldökosysteme Reihe A Nr. 123, 172 pp

Wagner S (1996) Übertragung strahlungsrelevanter Wetterinformation aus punktuellen PAR-Sensordaten in größere Versuchsflächenanlagen mit Hilfe hemisphärischer Fotos. Allg Forst J Ztg 167:34-40

Wagner S (1998) Calibration of grey values of hemispherical photographs for image analysis. Agric For Meteorol 90:103-117. doi: 10.1016/S0168-1923(97)00073-7

Wagner S (1999) Ökologische Untersuchungen zur Initialphase der Naturverjüngung in Eschen-Buchen-Mischbeständen. Schriftenreihe der Forstlichen Fakultät der Uni Göttingen und der Niedersächsischen Forstlichen Versuchsanstalt Göttingen Sauerländer's Verlag, $262 \mathrm{pp}$

Wagner S (2001) Relative radiance measurements and zenith angle dependent segmentation in hemispherical photography. Agric For Meteorol 107:103-115. doi:10.1016/S0168-1923(00) 00232-X

Wagner S, Lundqvist L (2004) Regeneration techniques and the seedling environment from a European perspective. In: Stanturf JA, Madsen P (eds) Restoration of boreal and temperate forests, Chapter 10. CRC Press, Boca Raton, pp 153-171

Wagner S, Küßner R, Ammer C, Dohrenbusch A (2004) Hinweise zur Erfassung von Strahlung und Kronenraumstruktur in Waldbeständen im Rahmen waldbaulicher Untersuchungen. Forstarchiv 75:110-121

Walters MB, Reich PB (1997) Growth of Acer saccarum seedlings in deeply shaded understories of northern Wisconsin: effects of 
nitrogen and water availability. Can J For Res 27:237-247. doi: $10.1139 /$ cjfr-27-2-237

Weiner J, Thomas SC (2001) The nature of tree growth and the "agerelated decline in forest productivity". Oikos 94:374-376. doi: 10.1034/j.1600-0706.2001.940219.x

Welander NT, Ottosson B (1998) The influence of shading on growth and morphology in seedlings of Quercus robur L. and Fagus sylvatica L. For Ecol Manage 107:117-126. doi:10.1016/ S0378-1127(97)00326-5

Wenk G, Antanaitis V, Smelko S (1990) Waldertragslehre. Deutscher Landwirtschaftsverlag, Berlin

Williams H, Messier C, Kneeshaw DD (1999) Effects of light availability and sapling size on the growth and crown morphology of understory Douglas-fir and lodgepole pine. Can J For Res 29:222-231. doi:10.1139/cjfr-29-2-222

Wu H-I, Sharpe PJH, Walker J, Penridge LK (1985) Ecological field theory: a spatial analysis of resource interference among plants. Ecol Modell 29:215-243. doi:10.1016/0304-3800(85)90054-7

Zerihun A, Ammer C, Montagu KD (2007) Evaluation of a semiempirical model for predicting fine root biomass in compositionally complex woodland vegetation. Ann For Sci 64:247-254. doi:10.1051/forest:2007002

Zhang G, Jiang H, Niu G, Liu X, Peng S (2006) Simulating the dynamics of carbon and nitrogen in litter-removed pine forest. Ecol Modell 195:363-376. doi:10.1016/j.ecolmodel.2005.11.041 